\title{
Effects of phytase on growth performance and digestibility of phosphorus in maize-soyabean meal based diets for young pigs*
}

\author{
Q.M. Yang and S.K. Baidoo ${ }^{1}$ \\ Southern Research and Outreach Centre, University of Minnesota \\ 35838-120 th Street, Waseca, MN 56093, USA
}

(Received 24 August 2004; revised version 30 December 2004; accepted 18 March 2005)

\begin{abstract}
Two hundred sixteen early-weaned piglets (initial BW $5.8 \pm 1.1 \mathrm{~kg}$ ) were used to evaluate the effects of microbial phytase (Natuphos ${ }^{\circledR}$ ) on growth performance and the digestibility of phosphorus $(\mathrm{P})$, crude protein $(\mathrm{CP})$ and organic matter $(\mathrm{OM})$ in maize-soyabean meal based diets. Pigs were allotted to three treatments with eight pigs per pen and nine pens per treatment. Pigs were phase-fed in two, two-week periods each. Three dietary total P levels combination (DM basis) for pigs in phase 1 and 2 were: 1 . control, 0.8 and $6.9 \mathrm{~g} \mathrm{P} / \mathrm{kg}$ diet (1.2 g P/kg diet from dicalcium phosphate DCP) without phytase, $2.50 \%$ $\mathrm{DCP}$ reduction of the control + phytase (50\% DCP reduction + phytase), 7.5 and $6.3 \mathrm{~g} \mathrm{P} / \mathrm{kg}$ diet $(0.6 \mathrm{~g}$ $\mathrm{P} / \mathrm{kg}$ diet from DCP) and 3. without supplementation + phytase (no DCP + phytase), 6.9 and $5.8 \mathrm{~g} \mathrm{P} / \mathrm{kg}$ diet, respectively. Phytase was added to the phytase-supplemented diets at a level of 500 phytase units $/ \mathrm{kg}$ of feed for both phases. Chromic oxide $(2.5 \mathrm{~g} / \mathrm{kg})$ was added to the diets as an indigestible marker to determine coefficient of total tract apparent digestibility (CTTAD) of feed. There were no differences $(\mathrm{P}>0.05)$ in overall average daily gain $(295,311$ and $297 \mathrm{~g} / \mathrm{d})$ and feed/gain $(1.47,1.46$ and 1.46) for the control, 50\% DCP reduction + phytase and no DCP + phytase diets, respectively. The CTTAD of organic $\mathrm{P}$ in the diets with added phytase was significantly higher $(\mathrm{P}<0.01)$ than in the control diet in both phase 1 ( 0.43 and 0.40 vs 0.32$)$ and 2 ( 0.42 and 0.36 vs 0.28$)$. The CTTAD of organic matter (OM) was also improved by phytase in phase 2. However, the CTTAD of inorganic P and CP was not influenced by phytase supplementation. Serum inorganic phosphorus concentration $(119 \mathrm{mg} / \mathrm{L})$ in pigs fed the diet with $50 \%$ DCP reduction + phytase was higher $(\mathrm{P}<0.05)$ than in pigs fed the control diet $(101 \mathrm{mg} / \mathrm{L})$ and the diet without DCP supplementation + phytase $(105 \mathrm{mg} / \mathrm{L})$ in phase 2 and was higher on $\mathrm{d} 1$ after weaning than in phase 1 and 2. In summary, phytase supplementation of reduced inorganic phosphorus diets, fed to young pigs, maintained performance and improved the digestibility of organic $\mathrm{P}$ and decreased the excretion of faecal phosphorus.
\end{abstract}

KEY WORDS: piglets, phytase, phosphorus

\footnotetext{
${ }^{*}$ Supported by Minnesota Department of Agriculture

${ }^{1}$ Corresponding author: e-mail: skbaidoo@umn.edu
} 


\section{INTRODUCTION}

A substantial amount of phosphorus (P) is excreted in manure because of the low digestibility of $\mathrm{P}$ in the cereal feedstuffs. This poses an environmental concern. Recent studies have shown that the addition of phytase to grain diets enables more of the phytate $\mathrm{P}$ to become available to non-ruminant animals so less inorganic P needs to be included in the diet. Simons et al. (1990) reported that the addition of microbial phytase to low $\mathrm{P}$ diets for growing pigs increased the apparent digestibility of $\mathrm{P}$ by $24 \%$. Consequently, the amount of $\mathrm{P}$ in the faeces was reduced by $35 \%$. Kemme et al. (1997) reported that phytase generated $0.17 \mathrm{~g}$ digestible $\mathrm{P} / \mathrm{kg}$ diet less in piglets than in the growing-finishing pigs. The improvement of bioavailability of $\mathrm{P}$ in maize-soyabean meal mixture for weaning pigs was also verified by Lei et al. (1993a,b), Murry et al. (1997), and Zhang et al. (2000). Sufficient $P$ is present in soyabean meal, maize and oats to meet the $P$ requirements of pigs, if a significant amount of phytate $\mathrm{P}$ could be made available (Cromwell et al., 1995). However, the early phase of nursery pigs is studying rather infrequently, as yet. Therefore, the purpose of the present study was to investigate the influence on piglet performance and to evaluate the efficacy of phytase (Natuphos ${ }^{\circledR}$ ) as a means of improving the bioavailability of organic $\mathrm{P}$ and other nutrients in maize-soyabean meal diets with reduced or obviate inorganic $\mathrm{P}$ supplementation.

\section{MATERIAL AND METHODS}

\section{Experimental diets}

Three maize-soyabean meal mash diets were formulated in two phases. The first phase diet contained $240 \mathrm{~g}$ crude protein $(\mathrm{CP}) / \mathrm{kg}$ diet fed for the first 2 weeks after weaning and the second phase diet contained $230 \mathrm{~g} \mathrm{CP} \mathrm{g} / \mathrm{kg}$ diet fed for 3rd and 4th week after weaning. Phosphorus in the control diet was supplemented entirely by inclusion of dicalcium phosphate (DCP). Diet 2 contained 50\% less DCP than diet 1 plus 500 phytase units $/ \mathrm{kg}$ diet (50\% DCP reduction + phytase), diet 3 contained 500 phytase units/kg diet without DCP supplementation (no DCP + phytase) (Table 1). A phytase unit is defined as the amount of enzyme that liberates $1 \mu \mathrm{mol}$ of inorganic $\mathrm{P}$ from sodium phytate per min at $\mathrm{pH} 5.5$ and $37^{\circ} \mathrm{C}$ (Engelen et al., 1994). Diet 1,2 and 3 in the first phase contained 8.0, 7.5 and $6.9 \mathrm{~g}$ total $\mathrm{P} / \mathrm{kg}$ diet and in the second phase contained $6.9,6.3$ and $5.8 \mathrm{~g}$ total $\mathrm{P} / \mathrm{kg}$ diet, respectively. Pigs 
fed diets 1, 2 and 3 in the first phase were accordingly feddiets 1, 2 and 3 in the second phase. All nutrients were supplied in the diets to meet or exceed current requirements for young pigs according to NRC (1998).

TABLE 1

Composition and the nutrient analyses of experimental diets

\begin{tabular}{|c|c|c|c|c|c|c|}
\hline \multirow[b]{2}{*}{ Indices } & \multicolumn{3}{|c|}{ Phase 1} & \multicolumn{3}{|c|}{ Phase 2} \\
\hline & control & $\begin{array}{c}50 \% \text { DCP } \\
+ \text { phyt }^{1}\end{array}$ & $\begin{array}{c}0 \mathrm{DCP}+ \\
\text { phyt }\end{array}$ & control & $\begin{array}{c}50 \% \text { DCP + } \\
\text { phyt }\end{array}$ & $\begin{array}{c}0 \mathrm{DCP}+ \\
\text { phyt }\end{array}$ \\
\hline \multicolumn{7}{|l|}{ Ingredients, $\mathrm{g} / \mathrm{kg}$} \\
\hline maize & 402 & 402 & 404.5 & 506 & 508 & 510.5 \\
\hline other ingredients $^{2}$ & 570 & 570 & 570 & 460 & 460 & 460 \\
\hline dicalcuim phosphate & 5 & 2.5 & 0 & 5 & 5 & 0 \\
\hline limestone & 4 & 6 & 6 & 10 & 10 & 10 \\
\hline Premix ${ }^{3}$ & 19 & 19 & 19 & 19 & 19 & 19 \\
\hline Natuphos ${ }^{\mathrm{TM}}$ (phytase) & - & 0.5 & 0.5 & - & 0.5 & 0.5 \\
\hline \multicolumn{7}{|c|}{ Determined analysis ${ }^{4}, \mathrm{~g} / \mathrm{kg} D M$} \\
\hline crude protein & 239 & 241 & 241 & 231 & 226 & 229 \\
\hline $\mathrm{Ca}$ & 9.5 & 9.7 & 9.2 & 9.1 & 9.1 & 8.9 \\
\hline total P & 8.0 & 7.5 & 6.9 & 6.9 & 6.3 & 5.8 \\
\hline organic $\mathrm{P}$ & 3.3 & 3.3 & 3.2 & 3.0 & 2.9 & 3.0 \\
\hline
\end{tabular}

${ }^{1}$ DCP: diacalcium phosphate; phyt: phytase at 500 phytase units $/ \mathrm{kg}$ diet

2 phase 1 diets contain; g/kg: soyabean meal, 240; fish meal, 80; whey powder, 120; oat, 100; tallow, 30. Phase 2 diets contain; g/kg: soyabean meal, 250; fish meal, 40; whey powder, 60; oat, 80; tallow, 30

${ }^{3}$ Premix supplied the following per kg of diet; mg: $\mathrm{Zn}, 100 ; \mathrm{Mn}, 20 ; \mathrm{Fe}, 100 ; \mathrm{Cu}, 15 ; \mathrm{I}, 0.45$; $\mathrm{Se}$, 0.25; IU: vit. A, 5,000; vit. $\mathrm{D}_{3}, 1,500$; vit. E, 30; mg: riboflavin, 5; nicacin, 20; pantothenic acid, 10; choline chloride, $1 \mathrm{~g}$; $\mathrm{mg}$ : folic acid, 0.3 ; vit. $\mathrm{K} 3,0.3$; vit. $\mathrm{B}_{12}, 18 \mu \mathrm{g}$; biotin, $0.05 \mathrm{mg}$, sodium chloride; g/kg: 5; lysine, 2; threonine, 1; tryptophane, 1; ASP250 (mg/kg: Chlortetracycline, 100; Sulfamethazine, 100; Procaine penicillin, 50); g/kg 5; chromic oxide, 2.5

${ }^{4}$ protein, $\mathrm{Ca}$ and $\mathrm{P}$ were based on chemical analysis. Organic $\mathrm{P}$ was determined by difference of total $\mathrm{P}$ - inorganic $\mathrm{P}$

\section{Animals and housing}

A total of 216 crossbred pigs (Cambrough $22 \times$ Duroc) was weaned at approximately $21 \pm 1.3 \mathrm{~d}$ with an average live weight of $5.8 \pm 1.1 \mathrm{~kg}$. All the pigs were divided into 9 blocks by body weight and sex. Each block was divided into 3 groups that were randomly allotted to three dietary treatments. There were nine replicates (pens) per treatment and 8 pigs per pen $(1.6 \times 1.9 \mathrm{~m})$ with tender foot flooring in an environmentally controlled building. Temperature was maintained at $30.5^{\circ} \mathrm{C}$ in the first week and decreased by about $2.0^{\circ} \mathrm{C}$ weekly with thermostatically controlled exhaust fans and heaters. Each pen had a nipple waterer and a self-feeder. Feed and water were available ad libitum. Pigs were 
weighed and feed intake was determined every week. The experimental protocols used in this study were approved by the University of Minnesota Institutional Animal Care and Use Committee (ILAE, 1996).

\section{Sample collection and measurements}

An indigestible marker, $\mathrm{Cr}_{2} \mathrm{O}_{3}$ was added to the diets at $2.5 \mathrm{~g} / \mathrm{kg}$ to determine the apparent total tract digestibility of total $\mathrm{P}$, organic $\mathrm{P}, \mathrm{CP}$ and organic matter (OM). Nine pigs were selected from 9 pens ( 1 pig/pen) per treatment for digestibility study. After a 7 days adjustment to the chromic oxide diets, faecal samples from the marked pigs were collected by faecal grab method twice daily for 4 consecutive days during each phase (about $200 \mathrm{~g} / \mathrm{pig}$ ). Collected samples were frozen immediately at $-20^{\circ} \mathrm{C}$. After each collection period, faeces from each pig were thawed, pooled together, homogenized and one sample was frozen at $-20^{\circ} \mathrm{C}$ until analyses for nitrogen $(\mathrm{N})$ and P. Fresh faecal samples were used for analysing $\mathrm{N}$ by the Kjeldahl method (AOAC, 1990) with a N2300 Nitrogen Analyser (FOSS, Höganös, Sweden). The stored faeces were dried at $105^{\circ} \mathrm{C}$ to obtain dried matter until constant weight. The dried samples were ground through a $1 \mathrm{~mm}$ screen, and 3 duplicate samples were prepared and analysed for total $\mathrm{P}$ and organic $\mathrm{P}$. Total $\mathrm{P}$ was determined colorimetrically by the vanadomolybdate procedure (AOAC, 1990). Inorganic $P$ in feed and faeces was determined after diluting with $\mathrm{HCl}$ to dry-matter content of about $1 \%$ and a 1.5 molarity for added $\mathrm{HCl}$ in a final volume of $100 \mathrm{ml}$. The phosphorus in the filtrate after filtering using Whatman filter paper (No. 1820-090, Maidstone, England) was quantitatively assayed by the spectrophotometry method described by Gerritse and Vriesema (1984). Organic P was taken as the difference between total and inorganic $\mathrm{P}$. The $\mathrm{OM}$ was equal to dry matter minus ash. The ash was determined by the ash weight after the dry samples were burned at $550^{\circ} \mathrm{C}$ until constant weight. The spectrophotometry method was used in measuring $\mathrm{Cr}_{2} \mathrm{O}_{3}$ in feed and faeces with 3 duplicate samples using 1,5-diphenylcarbohydrazilde $\left(\mathrm{C}_{13} \mathrm{H}_{14} \mathrm{~N}_{4} \mathrm{O}\right)$ as colorimetric agent as described in SSSA (1996).

\section{Blood sampling and measurements}

Blood samples were collected from 3 pigs per pen on day 1 after weaning and at the end of the first and second dietary phases. Serum samples were separated by centrifuging at $1850 \times \mathrm{g}$ for $10 \mathrm{~min}$, transferred to plastic sample tubes and stored at $-20^{\circ} \mathrm{C}$ until subsequent analysis for P. Inorganic $\mathrm{P}$ in the serum was assayed by the vanadomolybdate procedure (AOAC, 1990) after removing the protein by centrifuging the mixture of serum and trichloroacetic acid. 


\section{Statistics}

Individual pig was treated as experimental unit in the analysis of variance for the digestibility, faecal composition and serum $P$ for each treatment. Pen served as experimental unit for daily gain and feed efficiency. The data of serum inorganic $\mathrm{P}$ in different phases were treated as split plot design with repeated measurements at different time:

$$
\mathrm{Y}=\mu+\alpha \mathrm{i}+\operatorname{Di}(\mathrm{j})+\beta \mathrm{k}+\alpha \beta \mathrm{ik}+\varepsilon
$$

where $\alpha \mathrm{i}$ is $i$ th dietary treatment, $\beta_{\mathrm{k}}$ is $k$ th measurement, $\mathrm{D}_{\mathrm{i}(\mathrm{j})}$ is the whole-plot level random error, $\alpha \beta_{\text {ik }}$ is the interaction and $\varepsilon$ is the split-plot level random error. All the data analyses were performed using the general linear model (GLM) procedure of SAS (SAS, 2000) appropriate for a randomized complete block design for growth performance and digestibility or split block design for serum phosphorus (Aarou and Hays, 2000).

\section{RESULTS}

There were no effects $(\mathrm{P}>0.05)$ of dietary phytase supplementation on piglet performance in week 1, 2 and 4 (Table 2). However, the average daily gain (ADG) of pigs fed 50\% dicalcium phosphate (DCP) reduction + phytase diet was higher $(\mathrm{P}<0.05)$ than the pigs fed control diet $(464 \mathrm{vs} 413 \mathrm{~g} / \mathrm{kg}$ ) in week 3 (Table 2 ). The ADG of pigs fed the control, $50 \%$ DCP reduction + phytase and no DCP + phytase diets was 295, 311 and $297 \mathrm{~g}$ during the four week period. The average feed conversion ratio (feed/gain) during the experiment was 1.47, 1.46 and 1.46 for the pigs fed control, 50\% DCP reduction + phytase and no DCP + phytase diets, respectively, and the average feed intake was 404,411 and $400 \mathrm{~g} / \mathrm{d}$, respectively.

Phytase supplementation in the diet significantly improved $(\mathrm{P}<0.05)$ the digestibility of organic $\mathrm{P}$ during the phase 1 and phase 2 for the weaning pigs (Table 3). The digestibility of organic P for the no DCP + phytase diets in both phase 1 and phase 2 was higher $(\mathrm{P}<0.05)$ than those from the control diets; and the digestibility of organic $\mathrm{P}$ for the $50 \%$ DCP reduction + phytase diet was also higher $(\mathrm{P}<0.05)$ than those from the control diet in phase 1 (Table 3). However, the digestibility of organic $\mathrm{P}$ for the $50 \%$ DCP reduction + phytase diet was not different $(\mathrm{P}>0.05)$ from that for the control diets in phase 2 (Table 3). The digestibility of $\mathrm{OM}$ was improved by the phytase supplementation compared to the control diet in phase 2, but not in phase 1 (Table 3 ). The digestibility of total $\mathrm{P}$, inorganic $\mathrm{P}$ and $\mathrm{CP}$ was not influenced $(\mathrm{P}>0.05)$ by the phytase supplementation. 
TABLE 2

Growth performance of piglets fed diets with or without phytase supplementation

\begin{tabular}{|c|c|c|c|c|c|}
\hline Weeks & Control & $50 \% \mathrm{DCP}^{1}+$ phytase & $0 \mathrm{DCP}+$ phytase & SEM & $\mathrm{P}$ \\
\hline & ----------- & Daily gain, $g$ & ----------- & $\mathrm{n}=216$ & \\
\hline 1 & 60 & 57 & 57 & 4.28 & 0.62 \\
\hline 2 & 189 & 195 & 173 & 5.90 & 0.35 \\
\hline 3 & $413^{b}$ & $464^{\mathrm{a}}$ & $441^{\mathrm{ab}}$ & 8.93 & 0.03 \\
\hline \multirow[t]{2}{*}{4} & 519 & 528 & 517 & 4.74 & 0.45 \\
\hline & ----------- & Feed intake, $\mathrm{g} / \mathrm{d}$ & -------------- & $\mathrm{n}=9$ & \\
\hline 1 & 108 & 115 & 108 & 6.12 & 0.80 \\
\hline 2 & 260 & 269 & 234 & 9.55 & 0.29 \\
\hline 3 & 512 & 532 & 524 & 17.3 & 0.86 \\
\hline \multirow[t]{2}{*}{4} & 735 & 729 & 732 & 21.7 & 0.98 \\
\hline & ------------ & Feed/gain & ---- & $\mathrm{n}=9$ & \\
\hline 1 & 1.80 & 1.87 & 1.84 & 0.31 & 0.21 \\
\hline 2 & 1.41 & 1.44 & 1.40 & 0.02 & 0.86 \\
\hline 3 & 1.26 & 1.16 & 1.20 & 0.07 & 0.31 \\
\hline 4 & 1.42 & 1.38 & 1.41 & 0.03 & 0.46 \\
\hline
\end{tabular}

${ }^{1}$ DCP: diacalcium phosphate

figures with different letters in row are significantly different $(\mathrm{P}<0.05)$

TABLE 3

Digestibility coefficient of feed composition in nursery pigs fed diets supplemented with or without phytase

\begin{tabular}{|c|c|c|c|c|c|}
\hline Indices & Control & $\begin{array}{c}50 \% \mathrm{DCP}^{1}+ \\
\text { phytase }\end{array}$ & $\begin{array}{c}0 \text { DCP + } \\
\text { phytase }\end{array}$ & $\begin{array}{l}\text { SEM } \\
(\mathrm{n}=9)\end{array}$ & $\mathrm{P}$ \\
\hline & ------- & Phase 1 (week 1 - 2) & ------ & & \\
\hline Total P & 0.58 & 0.64 & 0.63 & 0.01 & 0.09 \\
\hline Inorganic $\mathrm{P}$ & 0.82 & 0.82 & 0.80 & 0.01 & 0.48 \\
\hline Organic P & $0.32^{\mathrm{b}}$ & $0.40^{\mathrm{a}}$ & $0.43^{\mathrm{a}}$ & 0.03 & $<0.01$ \\
\hline \multirow[t]{2}{*}{$\begin{array}{l}\text { Faecal organic } \mathrm{P} \\
\text { composition, } \%{ }^{2}\end{array}$} & 100 & 80 & 74 & - & - \\
\hline & -------- & Phase 2 (week 3 - 4) & ------ & & \\
\hline Total P & 0.52 & 0.57 & 0.53 & 0.01 & 0.10 \\
\hline Inorganic $\mathrm{P}$ & 0.80 & 0.80 & 0.77 & 0.01 & 0.48 \\
\hline Organic P & $0.28^{\mathrm{b}}$ & $0.36^{\mathrm{ab}}$ & $0.42^{\mathrm{a}}$ & 0.03 & $<0.01$ \\
\hline $\begin{array}{l}\text { Faecal organic } \mathrm{P} \\
\text { composition, } \%{ }^{2}\end{array}$ & 100 & 78 & 67 & - & - \\
\hline Organic matter & $0.76^{\mathrm{b}}$ & $0.82^{\mathrm{a}}$ & $0.80^{\mathrm{a}}$ & 0.01 & $<0.01$ \\
\hline
\end{tabular}

${ }^{1}$ DCP: diacalcium phosphate

${ }^{2}$ calculated from digestibility of organic $\mathrm{P}$ by taking the control as $100 \%$

figures with different letters in row are significantly different $(\mathrm{P}<0.05)$ 
The contents of organic $\mathrm{P}$ in faeces from the $50 \%$ DCP reduction + phytase and no DCP + phytase diets were decreased by 20 and $26 \%$ in phase 1 and 22 and $33 \%$ in phase 2, respectively, compared to those from the control diet because of the improvement of organic $\mathrm{P}$ digestibility (Table 3 ).

The concentration of phosphorus in serum of pigs fed the $50 \%$ reduction + phytase diet was higher than the control and the $0 \% \mathrm{DCP}+$ phytase diets in phase $2(\mathrm{P}<0.05)$, but not different among dietary treatments on day 1 after weaning or in phase 1 . The concentration of $\mathrm{P}$ in serum of pigs on day 1 after weaning was higher $(\mathrm{P}<0.05)$ than in phase 1 and phase 2 (Table 4$)$. The interaction between phases and diets for serum $\mathrm{P}$ was significant $(\mathrm{P}<0.05)$.

TABLE 4

Inorganic phosphorus concentration $(\mathrm{mg} / \mathrm{l})$ in serum of nursery pigs fed control and phytase supplemented diets

\begin{tabular}{lccccc}
\hline Indices & Control & $\begin{array}{c}50 \% \mathrm{DCP}^{1} \\
+ \text { phytase }\end{array}$ & $\begin{array}{c}0 \mathrm{DCP}+ \\
\text { phytase }\end{array}$ & Means & SEM \\
\hline Day 1 post-weaning & $129(27)$ & $131(27)$ & $129(26)$ & $130^{\mathrm{x}}(80)$ & 2.38 \\
Phase 1 & $116(26)$ & $111(27)$ & $109(27)$ & $112^{\mathrm{y}}(80)$ & 2.41 \\
Phase 2 & $101^{\mathrm{b}}(27)$ & $119^{\mathrm{a}}(27)$ & $105^{\mathrm{b}}(27)$ & $109^{\mathrm{y}}(81)$ & 2.31 \\
Means & $115(80)$ & $120(81)$ & $114(80)$ & & \\
SEM & 2.21 & 2.42 & 2.58 & & \\
Phase $\times$ diets & & $\mathrm{P}=0.04$ & & & \\
\hline
\end{tabular}

${ }^{1}$ DCP: diacalcium phosphate

figures with different letters $(\mathrm{a}, \mathrm{b})$ in row or in column $(\mathrm{x}, \mathrm{y})$ are different at $\mathrm{P}<0.05$

figures in the parentheses are numbers of pigs per treatment bled for serum samples

\section{DISCUSSION}

Studies indicated that dietary supplementation of phytase and decreased P in the diets did not affect pig performance (Yi et al., 1996; Harper et al., 1997). In our current study, reduction of $50 \%$ DCP with added 500 phytase units $/ \mathrm{kg}$ diet resulted in increase in weight gain in week 3 compared to control diet and maintained pig growth and feed conversion by the end of the 4 weeks study. Improvement of growth rate for young pigs has also been reported by Lei et al. (1993b). The pigs fed diets without DCP + phytase showed a similar performance as the control diets. This observation impacts the determination of the phytase activity added in early-weaned pig diets to obviate the need for inorganic supplements without influencing performance. Lei et al. (1993b) recommended that supplements of dietary phytase activity at 1.200 phytase units $/ \mathrm{kg}$ could maximize phytate-P utilization by weaning pigs and, thus, nearly, if not completely, eliminate the need for inorganic $\mathrm{P}$ supplements in maize-soyabean meal diets for weaning pigs. From 
the result of the current study, inorganic $\mathrm{P}$ supplements could be avoided in the diets by adding 500 phytase units/kg diet.

Lei et al. (1993b) reported that phytase was largely responsible for the observed improvements in utilization of phosphorus. The phytase hydrolyses phytates, with inositol penta- to mono-phosphates as intermediary products (Reddy et al., 1982). The digestibility of organic $\mathrm{P}$ in the diet without inorganic $\mathrm{P}$ supplementation had a higher tendency than that in the diet with $50 \%$ DCP reduction + phytase in phase one, which indicated that the presence of inorganic $\mathrm{P}$ inhibits phytase activity as reported by Ullah (1988) and Greiner et al. (1993).

Lei et al. (1993b) reported that pigs receiving supplemental phytase had a 23\% greater apparent digestibility of $\mathrm{P}$ than pigs receiving no supplemental phytase. An increase of $10 \%$ in the percentage of $P$ retention due to 500 phytase units $/ \mathrm{kg}$ of diet was reported in a study of Nasi (1990). Simons et al. (1990) reported that the addition of phytase at 1000 phytase units $/ \mathrm{kg}$ of feed to the diet of growing pigs (35 to $70 \mathrm{~kg}$ ) increased apparent digestibility of $\mathrm{P}$ by $24 \%$ and decreased the amount of $\mathrm{P}$ in the faeces by $35 \%$, which was similar as the results of the current study. The supplementation of pig diets with phytase improved the utilization of organic P from feedstuffs and reduced the usage of inorganic $\mathrm{P}$ supplementation. Of equal or greater importance is the $50 \%$ reduction of $\mathrm{P}$ in pig manure. However, this depends on the assumption that pigs can sustain low $\mathrm{P}$ intake continuously from weaning to market weight.

Phytase maintained the concentration of inorganic $\mathrm{P}$ in the serum of phytase fed pigs compared with the control fed pigs. The higher concentration of phosphorus in serum of pigs fed the diet with $50 \%$ dicalcium phosphate reduction + phytase indicates the improvement of $\mathrm{P}$ absorption. Young et al. (1993) reported that the addition of the microbial phytase at 500 and 1000 phytase units $/ \mathrm{kg}$ increased serum phosphorus compared with the positive control diet supplemented with inorganic phosphorus. However, Lei et al. (1993a) found that pigs that received 750 phytase units $/ \mathrm{kg}$ diet did not sustain plasma $\mathrm{P}$ concentrations. The reason of the above contradiction is unknown and need further study. The interaction between diets and phases was found because the serum P levels were different between phases among the dietary treatments. A higher concentration of serum $\mathrm{P}$ in the piglets on day 1 after weaning showed that milk might have supplied phosphorus and maintained the $\mathrm{P}$ at higher level than the other feed.

\section{CONCLUSIONS}

Addition of 500 phytase units per $\mathrm{kg}$ to a maize-soyabean meal nursery diet that contained 0 or $50 \%$ inorganic $\mathrm{P}$ of the control diet were effective in improving availability of organic phosphorus for weaning pigs. With the supplemental phytase, 
pig growth performance and serum $P$ concentration were maintained and faecal organic $\mathrm{P}$ excretion was reduced by 20 to $33 \%$. This will reduce the need for supplementing inorganic $\mathrm{P}$ at least $50 \%$ and greatly alleviate $\mathrm{P}$ pollution in the environment.

\section{ACKNOWLEDGEMENTS}

The authors would like to thank Roger Walker, Dick Goetz, Gary Dobberstein and Scott Jones for assistance with experiment.

\section{REFERENCES}

Aaron D.K., Hays V.M., 2000. Statistical techniques for the design and analysis of swine nutrition experiments. In: A.J. Lewis, L.L. Southern (Editors). Swine Nutrition. $2^{\text {nd }}$ Edition. CRC Press, Washington, DC, pp. 889-890

AOAC, 1990. Official Methods of Analysis, Association of Official Analytical Chemists. 15 $5^{\text {th }}$ Edition. Arlington, AV

Cromwell G.L., Coffey R.D., Monegue H.J., Randolph J.H., 1995. Efficacy of low-activity, microbial phytase in improving the bioavailability of phosphorus in corn-soybean meal diets for pigs. J. Anim. Sci. 73, 449-456

Engelen A.J., van der Heeft F.C.P., Randsdorp H., Smit E.L., 1994. Simple and rapid determination of phytase activity. J. AOAC Int. 77, 760-764

Gerritse R.G., Vriesema R., 1984. Phosphate distribution in animal waste slurries. J. Agr. Sci. 102, 159-161

Greiner R., Konietzny U., Jany K.I.-D., 1993. Purification and characterization of two phytases from Escherichia coli. Arch. Biochem. Biophys. 303, 107-113

Harper A.F., Kornegay E.T., Schell T.C., 1997. Phytase supplementation of low-phosphorus growingfinishing pig diets improves performance, phosphorus digestibility, and bone mineralization and reduces phosphorus excretion. J. Anim. Sci. 75, 3174-3186

ILAE, 1996. The Requirement and Recommendations of the Guide for the Care and Use of Laboratory Animals. Institutional Animal Care and Use Committee Guidebook. NIH Publication No. 92-3415. Department of Health and Human Services. Washington, DC

Kemme P.A., Jongbloed A.W., Mroz Z., Beynen A.C., 1997. The efficacy of Aspergillus niger phytase in rendering phytate phosphorus available for absorption in pigs is influenced by pig physiological status. J. Anim. Sci. 75, 2129-2138

Lei X.G., Ku P.K., Miller E.R., Yokoyama M.T., 1993a. Supplementing corn-soybean meal diets with microbial phytase linearly improves phytate phosphorus utilization by weaning pigs. J. Anim. Sci. 71, 3359-3367

Lei X.G., Ku P.K., Miller E.R., Yokoyama M.T., Ullrey D.E., 1993b. Supplementing corn-soybean meal diets with microbial phytase maximizes phytate phosphorus utilization by weanling pigs. J. Anim. Sci. 71, 3368-3375

Murry A.C., Lewis R.D., Amos H.E., 1997. Effect of microbial phytase in a pearl millet-soybean meal diet on apparent digestibility and retention of nutrients, serum mineral concentration, and bone mineral density of nursery pigs. J. Anim. Sci. 75, 1284-1291

Nasi M., 1990. Microbial phytase supplementation for improving availability of plant phosphorus in the diet of the growing pigs. J. Agr. Sci. 62, 435-443 
NRC, 1998. Nutrient Requirement of Swine. $10^{\text {th }}$ Edition. National Academy Press, Washington, DC Reddy N.R., Sathe S.K., Salunkhe D.K., 1982. Phytates in legumes and cereals. In: C.O. Chichester, E.M. Mrak, G.F. Stewart (Editors). Advances in Food Research. Academic Press, New York, pp. 1-92

SAS, 2000. SAS User‘s Guide:Statistics (V8). SAS Inst. Inc., Cary, NC

Simons P.C.M., Versteegh H.A.J., Jongbloed A.W., Kemme P.A., Slump P., Bos K.D., Wolters M.G.E., Beudeker R.F., Verschoor G.J., 1990. Improvement of phosphorus availability by microbial phytase in broilers and pigs. Brit. J. Nutr. 64, 525-540

SSSA, Series 5, 1996. Methods of Soil Analysis, Part 3. Chemical Methods. J.M. Bigham (Editor). Published by Soil Science Society of America, Inc. and American Society of Agronomy, Inc., Madison, Wisconsin

Ullah A.H.J., 1988. Production, rapid purification and catalytic characterization of extracellular phytase from Aspergillus ficuum. Prep. Biochem. 18, 443-458

Yi Z., Kornegay E.T., Ravindran V., Lindemann M.D., Wilson J.H., 1996. Effectiveness of Natuphos ${ }^{\circledR}$ phytase in improving the bioavailabilities of phosphorus and other nutrients in soybean meal-based semipurified diets for young pigs. J. Anim. Sci. 74, 1601-1611

Young L.G., Leunissen M., Atkinson J.L., 1993. Addition of microbial phytase to diets of young pigs. J. Anim. Sci. 71, 2147-2150.

Zhang Z.B., Kornegay E.T., Radcliffe J.S., Wilson J.H., Veit H.P., 2000. Comparison of phytase from genetically engineered Aspergillus and canola in weanling pig diets. J. Anim. Sci. 78, 2868-2878

\section{STRESZCZENIE}

\section{Wpływ dodatku fitazy do diety kukurydziano-sojowej na wzrost i strawność fosforu przez młode świnie}

Doświadczenie przeprowadzono na sześćdziesięciu wcześnie odsadzonych prosiętach (początkowa m.c. $5.8 \pm 1.1 \mathrm{~kg}$ ) celem zbadania wpływu dodatku mikrobiologicznej fitazy (Natuphos ${ }^{\circledR}$ ) do diet kukurydziano-sojowych na wzrost zwierząt oraz strawność fosforu (P), białka ogólnego i substancji organicznej. Prosięta podzielono na 3 grupy, po 8 prosiąt w klatce, i 9 kojców w grupie. Świnie były żywione okresowo w dwóch, dwutygodniowych okresach każdy. Podawane dawki zawierały 3 poziomy $\mathrm{P}$; wynosiły one w fazie 1 i 2: 1 . kontrolna; 0,8 i $6,9 \mathrm{~g} \mathrm{P} / \mathrm{kg}$ diety $(1,2 \mathrm{~g}$ P/kg diety w postaci fosforanu dwuwapniowego (DCP), bez fitazy; 2. 50\% DCP mniej niż w grupie kontrolnej + fitaza; 7,5 i 6,3 g P/kg diety $(0,6 \mathrm{~g} \mathrm{P} / \mathrm{kg}$ diety z DCP) i 3. bez dodatku DCP + fitaza; 6,9 i 5,8 P/kg diety, odpowiednio. Fitaze dodawano w obydwóch fazach doświadczenia w ilości 500 jednostek fitazy $/ \mathrm{kg}$ paszy. Trójtlenek chromu $(2,5 \mathrm{~g} / \mathrm{kg})$ podawano jako wskaźnik do oznaczenia całkowitej pozornej strawności (CTTAD) paszy.

Nie stwierdzono istotnych $(\mathrm{P}>0,05)$ różnic $\mathrm{w}$ średnich dziennych przyrostach $(295,311$ i $297 \mathrm{~g} / \mathrm{dzień})$ ani w wykorzystaniu paszy $(1,47 ; 1,46$ i 1,46$)$ między trzema grupami. CTTAD organicznego P diet z dodatkiem fitazy w obydwóch fazach była istotnie większa $(\mathrm{P}<0,01)$ niż diety kontrolnej (odpowiednio 0,43 i 0,40 vs 0,32 oraz 0,42 i 0,36 vs 0,28 ). CTTAD substancji organicznej była także poprawiona przez dodatek fitazy w 2 fazie doświadczenia.

Nie stwierdzono natomiast wpływu dodatku fitazy na strawność P nieorganicznego, biała ogólnego i substancji organicznej. Stężenie P nieorganicznego w surowicy krwi $(119 \mathrm{mg} / \mathrm{L})$ prosiąt $\mathrm{z}$ grupy 2 było wyższe $(\mathrm{P}<0,05)$ niż prosiąt kontrolnych $(101 \mathrm{~kg} / \mathrm{L})$ i z grupy $3(105 \mathrm{mg} / \mathrm{L}) \mathrm{w}$ drugiej fazie żywienia $\mathrm{i}$ było wyższe w pierwszym dniu po odsadzeniu niż w fazie $1 \mathrm{i} 2$.

$\mathrm{W}$ podsumowaniu stwierdzono, że dodatek fitazy do diet o zmniejszonej zawartości $\mathrm{P}$ nieorganicznego, stosowanych w żywieniu prosiąt, nie wpływa na wzrost, lecz poprawia strawność $\mathrm{P}$ organicznego i zmniejsza wydalanie P do środowiska. 